ORIGINAL ARTICLE

\title{
Adsorption of temperate phages of Lactobacillus delbrueckii strains and phage resistance linked to their cell diversity
}

\author{
V. Trucco, J. Reinheimer, A. Quiberoni and V.B. Suárez \\ Instituto de Lactología Industrial (Universidad Nacional del Litoral - CONICET), Santa Fe, Argentina
}

\section{Keywords}

dairy processes, lactic acid bacteria, Lactobacillus delbrueckii, phage resistance, temperate bacteriophages.

\section{Correspondence \\ Viviana B. Suárez, INLAIN (FIQ-UNL), Santiago del Estero 2829, 3000 Santa Fe, Argentina. \\ E-mail: vivisuar@fiqus.unl.edu.ar}

2010/1886: received 20 October 2010, revised 9 December 2010 and accepted 5 January 2011

doi:10.1111/j.1365-2672.2011.04945.x

\begin{abstract}
Aims: The aim of this work was to study the adsorption step of two new temperate bacteriophages (Cb1/204 and Cb1/342) of Lactobacillus delbrueckii and to isolate phage-resistant derivatives with interesting technological properties.

Methods and Results: The effect of divalent cations, $\mathrm{pH}$, temperature and cell viability on adsorption step was analysed. The $\mathrm{Ca}^{2+}$ presence was necessary for the phage $\mathrm{Cb} 1 / 342$ but not for the phage $\mathrm{Cb} 1 / 204$. Both phages showed to be stable at $\mathrm{pH}$ values between 3 and 8 . Their adsorption rates decreased considerably at $\mathrm{pH} 8$ but remained high at acid $\mathrm{pH}$ values. The optimum temperatures for the adsorption step were between 30 and $40^{\circ} \mathrm{C}$. For the phage $\mathrm{Cb} 1 / 342$, nonviable cells adsorbed a lower quantity of phage particles in comparison with the viable ones, a fact that could be linked to disorganization of phage receptor sites and/or to the physiological cellular state. The isolation of phage-resistant derivatives with good technological properties from the sensitive strains and their relationship with the cell heterogeneity of the strains were also made.

Conclusions: Characterization of the adsorption step for the first temperate Lact. delbrueckii phages isolated in Argentina was made, and phage-resistant derivatives of their host strains were obtained.

Significance and Impact of the Study: Some phage-resistant derivatives isolated exhibited good technological properties with the prospective to be used at industrial level.
\end{abstract}

\section{Introduction}

Lactic acid bacteria (LAB) are widely used in fermented dairy products to give them certain qualities and protect them against the action of food pathogenic and spoilage micro-organisms. Lactobacillus delbrueckii, in particular, is one of the most important industrial species as it is used, together with Streptococcus thermophilus, for yogurt production, and it is a fundamental component of the starters used for hard cheese manufacturing (Reinheimer et al. 1995, 1996; Curry and Crow 2003; Giraffa and Rossetti 2004).

Phage infections are the most important cause for slow acid production by LAB during industrial fermentations (Moineau 1999; Suárez et al. 2002; Moineau and Lévesque 2005; Emond and Moineau 2007). The economic losses and the public health consequences incurred when a phage infection occurs may be very significant (Josephsen and Neve 1998; Forde and Fitzgerald 1999). Fermentative dairy industries are, in that sense, those that show the best documented failed fermentations caused by phage infections (Neve 1996; Brussow 2001; Suárez et al. 2002; Moineau and Lévesque 2005).

The lysogenic state in LAB is considered a fundamental cause of bacteriophage entry into industrial environments (Zago et al. 2005, 2008). Thus, temperate phages can disturb the normal fermentation process when, by mutation, they become virulent phages against the host strain, overcoming the lysogenic immunity. Moreover, these released phages could find sensitive strains among the other starter strains and so attack them (Davidson et al. 1990). 
On the other hand, the cell heterogeneity in pure LAB cultures, particularly in Lact. delbrueckii, has been known for a long time. However, few studies have reported morphological diversity when the strains are cultured in complex media under optimal incubation conditions. Vescovo et al. (1990) have reported morphological and phenotypic variants for Lact. delbrueckii ssp. bulgaricus LB6 with different phage resistance. Suárez et al. (2008a) have reported the isolation of phage-resistant derivatives from morphological variants isolated from Lact. delbrueckii ssp. lactis Ab1, the phage resistance mechanisms involved and the derivatives obtained with good technological properties.

In this study, two temperate phages with their sensitive strains were used to characterize the adsorption step, taking into account different variables. In addition, the study aimed to isolate phage-resistant derivatives with interesting technological properties from the morphological variants obtained from the sensitive strains.

\section{Material and methods}

\section{Bacterial strains, phages and culture conditions}

Two temperate phages isolated at the INLAIN (Instituto de Lactología Industrial, Facultad de Ingeniería Química, Santa Fe, Argentina) from the commercial strain Lact. delbrueckii ssp. lactis Cb1 were used. These phages were named $\mathrm{Cb1} / 204$ and $\mathrm{Cb1} / 342$ and their sensitive strains were Lact. delbrueckii ssp. lactis 204 (L.l 204) and Lact. delbrueckii ssp. bulgaricus 342 (L.b 342), respectively. These phages were partially characterized by our group in a previous work (Suárez et al. 2008c). Sensitive strains were maintained as frozen stocks at $-80^{\circ} \mathrm{C}$ in reconstituted $(10 \% \mathrm{w} / \mathrm{v})$ commercial nonfat dried skimmed milk (RSM), or Mannose-Rogosa-Sharpe (MRS) broth (Biokar, Beauvais, France) supplemented with $15 \%(\mathrm{v} / \mathrm{v})$ of glycerol, and routinely reactivated overnight at $42^{\circ} \mathrm{C}$ in MRS broth. Phage stocks were prepared as described by Neviani et al. (1992) in MRS broth, adding $10 \mathrm{mmol} \mathrm{l}^{-1}$ of $\mathrm{CaCl}_{2}$ (MRS-Ca), and then stored at $4^{\circ} \mathrm{C}$ and frozen at $-80^{\circ} \mathrm{C}$ in the presence of $15 \%$ of glycerol. Phage enumerations (PFU ml ${ }^{-1}$ ) were performed by the double-layer plaque titration method (Svensson and Christiansson 1991), using MRS$\mathrm{Ca}$ agar added with $100 \mathrm{mmol} \mathrm{l}^{-1}$ of glycine (Lillehaug 1997).

\section{Adsorption studies}

Influence of calcium ion

The effect of calcium ions on the phage adsorption on Lact. delbrueckii cells was studied by the determination of adsorption kinetics in MRS and MRS-Ca broths (Biokar) according to Suárez et al. (2008b). Exponentially growing cultures $\left(\mathrm{OD}_{600 \mathrm{~nm}}=0.5\right)$ of the strains were centrifuged (12 $000 \mathrm{~g}$ for $4 \mathrm{~min}$ ) and resuspended at a concentration from $3 \times 10^{8}$ to $5 \times 10^{8} \mathrm{CFU} \mathrm{ml}^{-1}$ (determined by plate counts) in MRS and MRS-Ca broths. Each phage was added at a multiplicity of infection (m.o.i.) of about 0.02 , and the mixtures were incubated for adsorption at $37^{\circ} \mathrm{C}$. At time intervals, an aliquot was centrifuged $(12000 \mathrm{~g}$ for $4 \mathrm{~min}$ ) to sediment the phage-adsorbed cells. Then, the number of free phages in the supernatant was determined, and the results were expressed as percentages of the initial phage counts.

\section{Influence of $p H$}

Cells prepared according to the same protocol used in the previous experience were resuspended in MRS-Ca broth, adjusted to the desired $\mathrm{pH}$ values $(3,4,5,6,7$ and 8). Phages were added (m.o.i.: 0.02) and the mixtures incubated for $30 \mathrm{~min}$ at $37^{\circ} \mathrm{C}$. After centrifugation, the supernatants were assayed for unadsorbed phages and their counts compared with the initial titre. Results were expressed as percentages of adsorption and plotted against $\mathrm{pH}$ values. Phage suspensions in $\mathrm{pH}$-adjusted MRS-Ca broth were included as controls to determine the $\mathrm{pH}$ effect on phage infectivity.

\section{Influence of temperature}

Phage adsorption rates on Lact. delbrueckii cells were determined at $0,10,20,30$ and $40^{\circ} \mathrm{C}$ as follows: exponentially growing cells $\left(\mathrm{OD}_{600 \mathrm{~nm}}: 0 \cdot 5\right)$ were centrifuged and resuspended in MRS-Ca broth. Phages were added (m.o.i.: 0.02) and the mixtures incubated for $30 \mathrm{~min}$. After centrifugation, supernatants were assayed for unadsorbed phages and counts were compared with the control titre without cells. Results were expressed as percentage of adsorption.

\section{Influence of cell viability}

The adsorption kinetics of viable and nonviable Lact. delbrueckii cells were also determined. Cells were prepared according to the same protocol used in the previous experiences. Nonviable cells (checked by plate counts) were obtained by keeping a cell suspension in boiling water for $10 \mathrm{~min}$ (Quiberoni and Reinheimer 1998).

\section{Isolation of phage-resistant derivatives from morphological variants}

Lactobacillus delbrueckii-sensitive strains were streaked on MRS (Biokar) agar (Suárez et al. 2008a). The plates were incubated at $37^{\circ} \mathrm{C}$ for $48 \mathrm{~h}$. Morphological variants were scored, isolated and cultured in MRS broth. 
The secondary culture method (SC) (Carminati et al. 1993) was used to isolate phage-resistant derivatives, which is modified as follows: an overnight culture of each strain in MRS-Ca broth was infected, at different infection ratios (m.o.i. of $1,0 \cdot 1$ and $0 \cdot 01$ ), with suspensions of the corresponding lytic phage. After incubation at $37^{\circ} \mathrm{C}$ for 6-8 h, cultures exhibited complete lysis. SCs were obtained after further incubation for up to $48 \mathrm{~h}$ at $37^{\circ} \mathrm{C}$ and streaked on MRS agar plates. After incubation for $48 \mathrm{~h}$ at $37^{\circ} \mathrm{C}$, colonies of each variant were isolated and cultured in MRS broth. These isolates were purified by three consecutive streakings on MRS agar. Phage resistance was confirmed by confronting each isolate cultivated in MRS-Ca broth with the corresponding lytic phage. Three subcultures were prepared, and isolates that were able to grow normally under these conditions were considered as true phage-resistant derivatives (Reinheimer et al. 1993) and stored at $-80^{\circ} \mathrm{C}$. Phage resistance stability was assayed by seven sequential subcultures $(2 \%)$ of the derivatives in MRS-Ca broth with independent infection with phages at each subculture (Carminati et al. 1993). The loss of phage resistance was determined by the culture lysis in comparison with a control (mutant subculture without phage addition). The subculture at which lysis occurred was recorded.

\section{Technological characterization of phage-resistant derivatives}

The proteolytic and acidifying activities were determined according to Guglielmotti et al. (2006).

\section{Statistical analysis}

To compare the results of technological properties obtained for the parental strains and their phage-resistant derivatives, a statistical one-way ANOva analysis was made. The significance level $(P)$ taken to consider significant differences was $0 \cdot 05$.

\section{Results}

\section{Adsorption studies}

\section{Influence of calcium ion.}

The adsorption kinetics in the presence and absence of calcium for the systems Cb1/204-L.l 204 and Cb1/342L.b 342 are shown in Fig. 1. For Cb1/204-L.l 204, it was observed that both adsorption kinetics, either in the presence or absence of the cation, showed the same trend. By contrast, a different behaviour was observed for Cb1/342-L.b 342. In this case, the absence of calcium ion delayed the phage adsorption on the sensitive

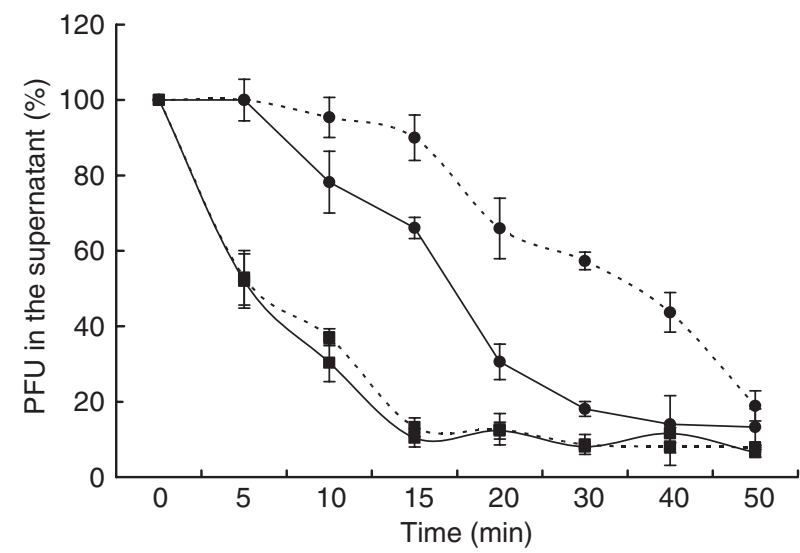

Figure 1 Calcium ion influence on the adsorption kinetics (at $37^{\circ} \mathrm{C}$ ) for phages Cb1/204 $(\square)$ and Cb1/342 (0), on their sensitive strains Lactobacillus delbrueckii ssp. lactis 204 and Lact. delbrueckii ssp. bulgaricus, respectively, with (-) and without (- - -) $\mathrm{Ca}^{2+}\left(10 \mathrm{~mm} \mathrm{I}^{-1}\right)$. Values are the mean and standard deviation of three determinations.

strain, although the adsorption rates at $50 \mathrm{~min}$ were similar.

\section{Influence of $\mathrm{pH}$}

It was found that the $\mathrm{pH}$ did not affect the survival of both phages (data not shown). Decreased adsorption rates were observed for the phage $\mathrm{Cb1} / 204$ on its host strain L.l 204 when $\mathrm{pH}$ values were extreme (3 and 8). Furthermore, the maximum adsorption occurred at $\mathrm{pH}$ values between 5 and 7 . Regarding the other system, the adsorption rate of the phage Cb1/342 on its host strain L.b 342 was affected only at $\mathrm{pH} 8$ (Fig. 2).

\section{Influence of temperature}

Adsorption rates for phages $\mathrm{Cbl} / 204$ and $\mathrm{Cbl} / 342$ at different temperatures on their sensitive strains L.l 204 and L.b 342, respectively, are shown in Fig. 3. For both cases, it was observed that the adsorption processes were influenced by the incubation temperature and that high rates of phage adsorption were attained even at low temperatures. In addition, it was found that the optimum temperatures for phage adsorption were $40^{\circ} \mathrm{C}$ for phage $\mathrm{Cb} 1 / 204$, with an adsorption rate of $99 \%$, and $30-40^{\circ} \mathrm{C}$ for phage $\mathrm{Cb} 1 / 342$, with an adsorption rate of $85 \%$.

\section{Influence of cell viability}

Figure 4 shows the phage adsorption kinetics on viable and nonviable cells. A higher percentage of phage Cb1/204 particles was adsorbed/was seen to be adsorbed on nonviable than on viable cells at early times, but after $15 \mathrm{~min}$, the adsorption rates on viable and nonviable $L . l$ 204 cells were the same. Contrary to the system 


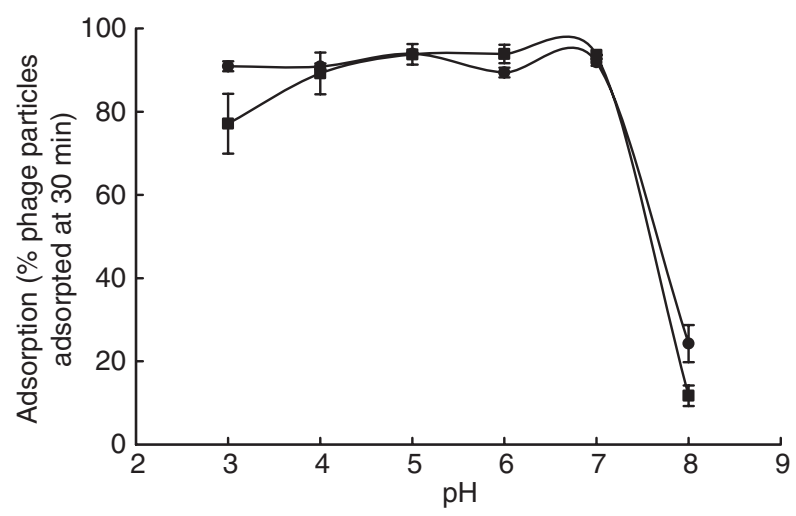

Figure $2 \mathrm{pH}$ value influence on the adsorption step $\left(30 \mathrm{~min}\right.$ at $37^{\circ} \mathrm{C}$ ) for phages Cb1/204 ( $)$ and Cb1342 (-) on their sensitive strains Lactobacillus delbrueckii ssp. lactis 204 and Lact. delbrueckii ssp. bulgaricus, respectively. Values are the mean and standard deviation of three determinations.

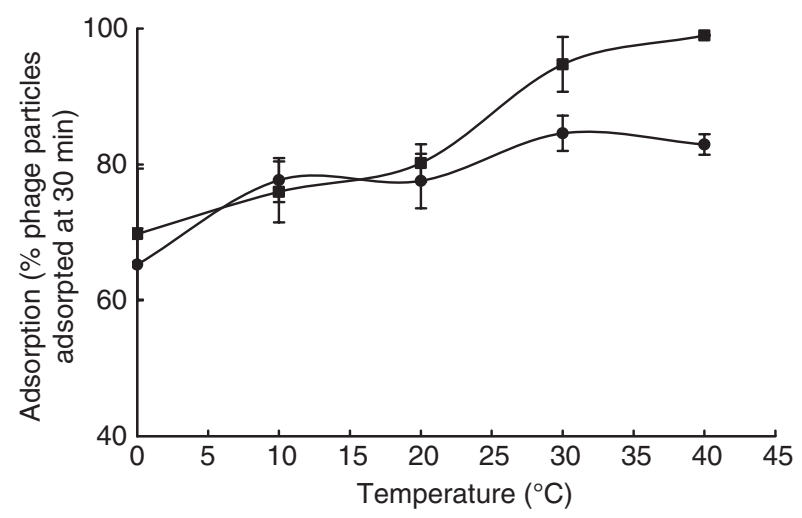

Figure 3 Temperature influence on the adsorption step (30 min at 0 , $10,20,30$ and $40^{\circ} \mathrm{C}$ ) for phages $\mathrm{Cb} 1 / 204(\boldsymbol{\square})$ and $\mathrm{Cb} 1342(\mathbf{0})$ on their sensitive strains Lactobacillus delbrueckii ssp. lactis 204 and Lact. delbrueckii ssp. bulgaricus, respectively. Values are the mean and standard deviation of three determinations.

Cb1/204-L.l 204, a higher percentage of phage Cb1/342 particles was adsorbed on viable cells compared with nonviable cells, this being significant at $30 \mathrm{~min}$. At this time, only $57 \%$ of phage particles was adsorbed on nonviable cells, while the adsorption percentage on viable cells was $82 \%$, approximately.

\section{Isolation of morphological variants}

For the strain L.l 204 (Fig. 5a), it was possible to obtain two colony morphologies: variant A $(44 \%$ of the total colonies) appeared as a large colony with a white centre and irregular edges, while variant B showed a smaller size, with regular edges and whitish. For the strain L.b 342, it was possible to isolate two morphological variants: variant

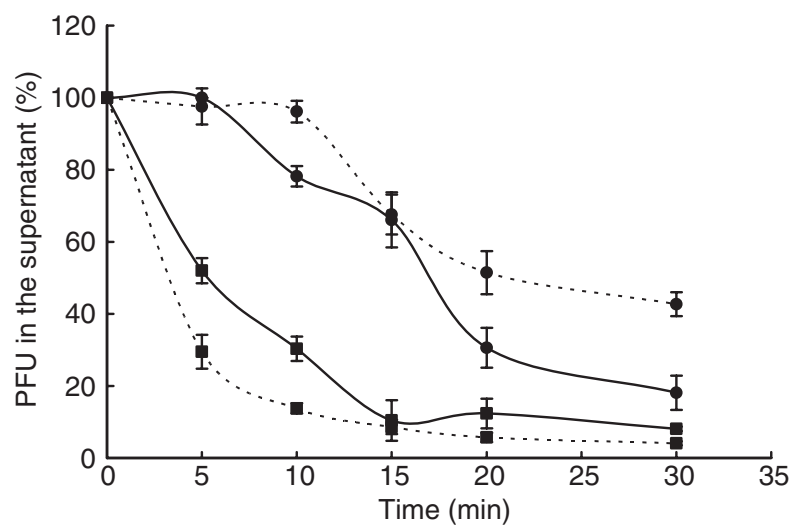

Figure 4 Cellular viability on the adsorption kinetics (at $37^{\circ} \mathrm{C}$ ) for phages $\mathrm{Cb1/204}(\square)$ and Cb1/342 (O) on their sensitive strains Lactobacillus delbrueckii ssp. lactis 204 and Lact. delbrueckii ssp. bulgaricus, respectively, viable (-) and nonviable (- - -) cells. Values are the mean and standard deviation of three determinations.

A (32\% of the total colonies) was smaller and white, while the variant B was large and whitish (Fig. 5b). Variants maintained their morphology after subcultures.

\section{Isolation of phage-resistant derivatives}

The percentages of phage-resistant derivatives isolated from each morphological variant for the two phage-host strain systems are shown in Table 1. For both strains, at low m.o.i values, the most phage-resistant derivatives belonged to the variants B (67\% for L.l 204 and 57\% for L.b 342). When the value of m.o.i. increased, the percentage of phageresistant derivatives varied according to the strain.

All the phage-resistant derivatives obtained (ten from both strains, five for each morphological variant) showed stability for this phenotype (by seven sequential subcultures with independent infection with phages at each subculture).

\section{Technological characterization of phage-resistant derivatives}

Acidifying and proteolytic activities obtained for both sensitive strains and their phage-resistant derivatives are shown in Table 2. For the strain L.l 204, derivatives with higher acidifying activity were isolated from both variant types but mainly for the variant B. Furthermore, phageresistant derivatives with a good acidifying activity were clearly isolated from variant B of the strain L.b 342 . According to the statistical analysis, the differences were significant between derivatives from $\mathrm{A}$ and $\mathrm{B}$ variants $(P<0.05)$ of both strains. As regards the proteolytic activity, significant differences between A and B variants were found only for the strain L.b 342 . 
Figure 5 Morphological variants obtained from MRS agar for L./ 204 (a) and L.b 342 (b) strains. Variant $A$ is shown as a dotted line (- - -) and variant B as a full line (-)
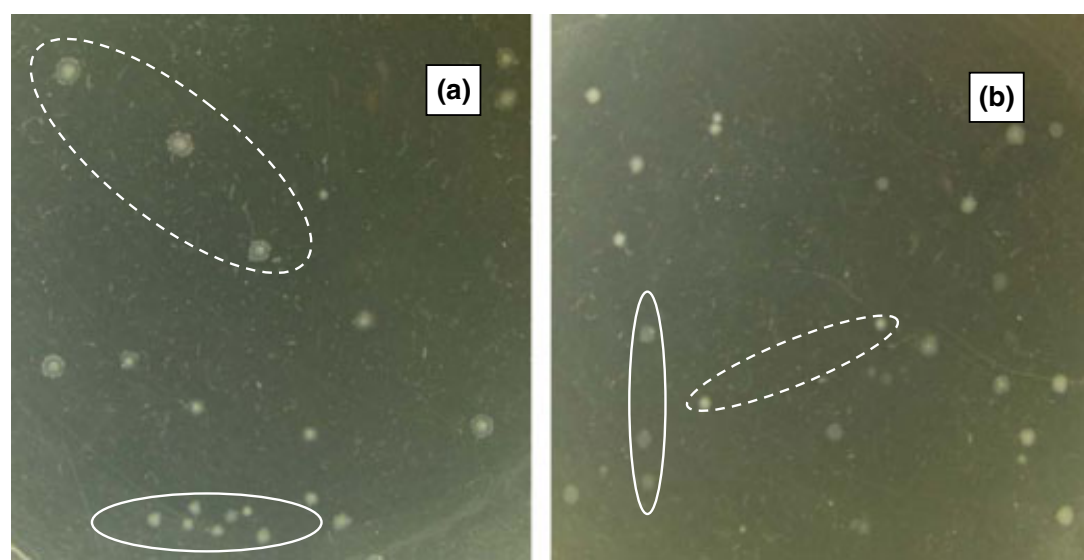

Table 1 Percentages of phage-resistant derivatives obtained from variants A and B of L.I 204- and L.b 342-sensitive strains, when infected with their specific phages

\begin{tabular}{|c|c|c|c|c|}
\hline \multirow[b]{3}{*}{$\begin{array}{l}\text { Multiplicity } \\
\text { of infection } \\
\text { (m.o.i.) }\end{array}$} & \multicolumn{4}{|l|}{ Strain } \\
\hline & \multicolumn{2}{|l|}{ L.I 204} & \multicolumn{2}{|l|}{ L.b 342} \\
\hline & $\begin{array}{l}\text { Derivatives } \\
(\%) \text { from } \\
\text { variant A }\end{array}$ & $\begin{array}{l}\text { Derivatives } \\
(\%) \text { from } \\
\text { variant B }\end{array}$ & $\begin{array}{l}\text { Derivatives } \\
(\%) \text { from } \\
\text { variant A }\end{array}$ & $\begin{array}{l}\text { Derivatives } \\
(\%) \text { from } \\
\text { variant B }\end{array}$ \\
\hline 1 & - & - & 12.5 & $87 \cdot 5$ \\
\hline $10^{-1}$ & $57 \cdot 0$ & $43 \cdot 0$ & $42 \cdot 0$ & 58.0 \\
\hline $10^{-2}$ & $62 \cdot 0$ & 38.0 & $43 \cdot 0$ & $57 \cdot 0$ \\
\hline $10^{-3}$ & $33 \cdot 0$ & $67 \cdot 0$ & - & - \\
\hline
\end{tabular}

\section{Discussion}

The first step in the phage biology is the adsorption on the host cell surface. Phage adsorption process was studied for several species of LAB (Sijtsma et al. 1988; Valsayevi et al. 1990; Monteville et al. 1994; Caso et al. 1995; Foschino et al. 1995; Quiberoni and Reinheimer 1998; Binetti et al. 2002; Quiberoni et al. 2004; Capra et al. 2006; Müller-Merbach et al. 2007; Suárez et al. 2008b; Briggiler Marcó et al. 2010). All these studies have been performed for lytic phages, the temperate ones being the least studied.

In this study, it was demonstrated that $\mathrm{Ca}^{2+}$ was necessary either for adsorption or for completion of the lytic cycle of the phage $\mathrm{Cb} 1 / 342$. The final adsorption values (50 min) were similar, but the previous values were substantially lower when the calcium ion was not used. This fact would mean that, for this system, the stage of adsorption would be improved in the presence of the cation, whereas its absence would lead to a delayed lysis of the sensitive strain in liquid medium. On the contrary, the phage $\mathrm{Cbl} / 204$ adsorption on its sensitive strain
Table $2 \mathrm{pH}$ values and proteolytic activity (OPA test) determined in LDR $\left(24 \mathrm{~h}\right.$ at $\left.37^{\circ} \mathrm{C}\right)$ for the sensitive strains and their phage-resistant derivatives

\begin{tabular}{|c|c|c|}
\hline $\begin{array}{l}\text { Strain/ } \\
\text { derivatives }\end{array}$ & $\mathrm{pH}^{*}$ & $\begin{array}{l}\text { Proteolytic } \\
\text { activity* }\left(A_{340 \mathrm{~nm}}\right.\end{array}$ \\
\hline L.I 204 & $4.07 \pm 0.03$ & $0.050 \pm 0.010$ \\
\hline RA204/1 & $4.42 \pm 0.02$ & $0 \cdot 300 \pm 0 \cdot 100$ \\
\hline RA204/2 & $4 \cdot 19 \pm 0 \cdot 02$ & $0.220 \pm 0.050$ \\
\hline RA204/3 & $4 \cdot 31 \pm 0.05$ & $0.310 \pm 0.060$ \\
\hline RA204/4 & $4 \cdot 82 \pm 0.04$ & $0.037 \pm 0.008$ \\
\hline RA204/5 & $4.55 \pm 0.02$ & $0.270 \pm 0.010$ \\
\hline RB204/1 & $4 \cdot 16 \pm 0 \cdot 06$ & $0.210 \pm 0.030$ \\
\hline RB204/2 & $3.79 \pm 0.01$ & $0.260 \pm 0.040$ \\
\hline RB204/3 & $4.21 \pm 0.02$ & $0.183 \pm 0.003$ \\
\hline RB204/4 & $4.05 \pm 0.03$ & $0.250 \pm 0.060$ \\
\hline RB204/5 & $3.85 \pm 0.02$ & $0.250 \pm 0.020$ \\
\hline L.b 342 & $3 \cdot 87 \pm 0.01$ & $0.434 \pm 0.001$ \\
\hline RA342/1 & $4.74 \pm 0.03$ & $0.348 \pm 0.002$ \\
\hline RA342/2 & $4.03 \pm 0.04$ & $0 \cdot 170 \pm 0 \cdot 010$ \\
\hline RA342/3 & $4.62 \pm 0.03$ & $0.060 \pm 0.003$ \\
\hline RA342/4 & $4.92 \pm 0.05$ & $0.106 \pm 0.006$ \\
\hline RA342/5 & $4.87 \pm 0.02$ & $0.041 \pm 0.004$ \\
\hline RB342/1 & $3.71 \pm 0.04$ & $0.420 \pm 0.010$ \\
\hline RB342/2 & $3.66 \pm 0.06$ & $0.460 \pm 0.001$ \\
\hline RB342/3 & $3.81 \pm 0.03$ & $0.503 \pm 0.006$ \\
\hline RB342/4 & $3.74 \pm 0.04$ & $0.342 \pm 0.003$ \\
\hline RB342/5 & $3.65 \pm 0.05$ & $0.461 \pm 0.004$ \\
\hline
\end{tabular}

*Values are the mean and standard deviation of three determinations.

Lact. delbrueckii ssp. lactis 204 was independent of the calcium presence. Unfortunately, the use of phage inhibitory media that contain chelating agents (phosphates and citrates) might not be useful to control those bacteriophages, because they do not require cations to complete their lytic cycle (Suárez et al. 2007). Séchaud et al. (1988) reported that $\mathrm{Ca}^{2+}$ is useful for the phage DNA penetration into the cells. However, this does not seem true for all phage-sensitive strain systems. For other lactobacilli 
phages, the requirement of calcium either for adsorption or for lysis was variable (Quiberoni and Reinheimer 1998; Binetti et al. 2002; Quiberoni et al. 2004; Capra et al. 2006; Suárez et al. 2008b; Briggiler Marcó et al. 2010).

Both phages showed to be stable at $\mathrm{pH}$ values between 3 and 8 . This fact could be explained by the origin of these phages. Temperate phages might have a high acidic resistance because acidity is a factor that induces these phages to release from the lysogenic strain, as a defence mechanism. The adsorption rates for both phages decreased considerably at $\mathrm{pH} 8$, as opposed to the results reported by Suárez et al. (2008b) who demonstrated an efficient adsorption of Lactococcus phages on their host strains. Binetti et al. (2002) reported the adsorption rates for six Strep. thermophilus phages, and the results showed a high adsorption at $\mathrm{pH}$ 8. Similar results were found by Briggiler Marcó et al. (2010) for four Lactobacillus plantarum bacteriophages. At acid $\mathrm{pH}$ values (up to $\mathrm{pH} 3$ ), temperate phages evidenced high adsorption rates. In general, bacteriophages infecting other LAB showed a lower adsorption at this $\mathrm{pH}$ value (Binetti et al. 2002; Capra et al. 2006; Briggiler Marcó et al. 2010).

Regarding the effect of incubation temperatures on the adsorption step, it was possible to observe that this process was dependent on this parameter and, even at $0^{\circ} \mathrm{C}$, the adsorption rates were high (60-70\%). Previous reports showed that Lactococcus lactis (Suárez et al. 2008b) and Lact. delbrueckii (Quiberoni et al. 2004) phages did not modify significantly the adsorption rates on their host strains with incubation temperature. On the contrary, Strep. thermophilus (Binetti et al. 2002), Lactobacillus paracasei (Capra et al. 2006) and Lact. plantarum (Briggiler Marcó et al. 2010) phages showed a remarkable dependence on temperature, especially at low ones.

In this work, the ability of thermally treated cells to adsorb phages was also evaluated. For the system Cb1/204- $L b$ 204, the adsorption rate on heat-treated cells was higher than that obtained on untreated cells, but this difference was not significant. On the contrary, the adsorption rate was affected by the temperature in the system Cb1/342- $L b$ 342. Nonviable cells adsorbed a lower quantity of phage particles in comparison with the viable ones. A behaviour similar to that of the phage Cb1/204 was exhibited by specific phages of Lact. delbrueckii (Quiberoni et al. 2004), Strep. thermophilus (Quiberoni and Reinheimer 1998; Binetti et al. 2002), Lactobacillus casei (Capra et al. 2006) and L. lactis (Suárez et al. 2008b). The lower phage adsorption observed on thermally treated cells could be linked to the disorganization of phage receptor sites and/or to the physiological cellular state (lack of bacterial energy). Further studies would be needed to discern the mechanisms involved in the decrease in the adsorption on nonviable cells.
Cell heterogeneity in cultures growing under unchanging and nutritionally nonlimiting environmental conditions has been poorly studied in the Lactobacillus genus. A large cell variability leading the clonal multiplication of subpopulations with differences in the phenotypic expression of lysozyme resistance was described in Lactobacillus helveticus (Veaux et al. 1991). Suárez et al. (2008a) reported the isolation of two clearly different colony morphologies for the commercial strain Lact. delbrueckii ssp. lactis Ab1. These results were similar to those found in Lact. delbrueckii ssp. bulgaricus LB6 (Vescovo et al. 1990) and Lactobacillus acidophilus RL8K (Klaenhammer and Kleeman 1981). In this work, two morphological variants were found from both sensitive strains. As regards the phage-resistant phenotype, the proportion of derivatives belonging to the different morphological variants was dependent on the m.o.i. used.

The isolation of phage-resistant derivatives with good technological properties is a simple resource to select 'new' strains from those frequently used in the industry. Many studies have been reported about this topic, mainly based on the effective isolation of phage-resistant derivatives for lytic phages (Neviani et al. 1992; Carminati et al. 1993; Viscardi et al. 2003a,b; Binetti et al. 2006, 2007; Guglielmotti et al. 2006). However, no information is available on this topic for temperate phages. The results obtained in this work showed that it was possible to isolate phage-resistant derivatives with technological properties similar or better than the strains from which they were obtained. The best technological derivatives, for both sensitive strains, belonged to the morphological variant $B$.

It is concluded that this work makes a significant contribution to the knowledge of the adsorption stage for temperate phages of Lact. delbrueckii, which would permit the 'regulation' of this stage, for example, using phage inhibitors media. It was possible to corroborate that the phage resistance derivatives for the both host strains that presented the best technological properties always belonged to one morphological variant.

\section{Acknowledgements}

This work was supported by the Universidad Nacional del Litoral (Santa Fe, Argentina) (Programación CAI+D 2009, Secretaria de Ciencia y Técnica, Proyecto No. 57275 ) and the Consejo Nacional de Investigaciones Científicas y Técnicas (CONICET, Argentina) (Project PIP 2009 No. 112-200801-01206).

\section{References}

Binetti, A., Quiberoni, A. and Reinheimer, J. (2002) Phage adsorption to Streptococcus thermophilus. Influence of 
environmental factors and characterization of cellreceptors. Food Res Int 35, 73-83.

Binetti, A., Bailo, N. and Reinheimer, J. (2006) Spontaneous phage-resistant mutants of Streptococcus thermophilus: isolation and technological characteristics. Int Dairy J 17, 343-349.

Binetti, A., Suárez, V., Tailliez, P. and Reinheimer, J. (2007) Characterization of spontaneous phage-resistant variants of Streptococcus thermophilus by randomly amplified polymorphic DNA analysis and identification of phage-resistant mechanisms. Int Dairy J 17, 1115-1122.

Briggiler Marcó, M., Reinheimer, J. and Quiberoni, A. (2010) Phage adsorption to Lactobacillus plantarum: influence of physiological and environmental factors. Int J Food Microbiol 138, 270-275.

Brussow, H. (2001) Phages of dairy bacteria. Annu Rev Microbiol 55, 283-303.

Capra, M.L., Quiberoni, A.L., Ackermann, H.-W., Moineau, S. and Reinheimer, J.A. (2006) Characterization of a new virulent phage (MLC-A) of Lactobacillus paracasei. J Dairy Sci 89, 2414-2424.

Carminati, D., Zennaro, R., Neviani, E. and Giraffa, G. (1993) Selezione e caratteristiche di mutanti fago-resistenti di Lactobacillus helveticus. Sci Tech Latt Cas 44, 33-48.

Caso, J.L., de los Reyes-Gavilán, C.G., Herrero, M., Montilla, A., Rodríguez, A. and Suarez, J.E. (1995) Isolation and characterization of temperate and virulent bacteriophage of Lactobacillus plantarum. J Dairy Sci 78, 741-750.

Curry, B. and Crow, V. (2003) Lactobacillus spp.: general characteristics. In Encyclopedia of Dairy Science ed. Roginski, H., Funquay, J. and Fox, P. pp. 1479-1511. Cornwall, UK: Academic Press Elsevier Science.

Davidson, B., Powell, I.B. and Hillier, A.J. (1990) Temperate bacteriophages and lysogeny in lactic acid bacteria. FEMS Microbiol Rev 87, 79-90.

Emond, E. and Moineau, S. (2007) Bacteriophages and food fermentations. In Bacteriophage: Genetics and Molecular Biology ed. McGrath, S. and van Sinderen, D. pp. 93-124. New York, USA: Horizon Scientific Press/Caister Academic Press.

Forde, A. and Fitzgerald, G.F. (1999) Bacteriophage defense system in lactic acid bacteria. In Proceedings of the Sixth Symposium on Lactic Acid Bacteria: Genetics, Metabolism and Applications ed. Konings, W.N., Kuipers, O.P. and Huis in 't Veld, J.H.J. pp. 89-113. Veldhoven, the Netherlands: Kluwer Academic Publishers.

Foschino, R., Perrone, F. and Galli, A. (1995) Characterization of two virulent Lactobacillus fermentum bacteriophages isolated from sourdough. J Appl Bacteriol 79, 677-683.

Giraffa, G. and Rossetti, L. (2004) Monitoring of the bacterial composition of dairy starter cultures by RAPD-PCR. FEMS Microbiol Lett 237, 133-138.

Guglielmotti, D., Reinheimer, J., Binetti, A., Giraffa, G., Carminati, D. and Quiberoni, A. (2006) Characterization of spontaneous phage-resistant derivatives of Lactobacillus delbrueckii commercial strains. Int J Food Microbiol 111, 126-133.

Josephsen, J. and Neve, H. (1998) Bacteriophages and lactic acid bacteria. In Lactic Acid Bacteria. Microbiology and Functional Aspects ed. Salminen, S. and von Wright, A. pp. 385-436. New York: Marcel Decker Inc.

Klaenhammer, T. and Kleeman, E. (1981) Growth characteristics, bile sensitivity and freeze damage in colonial variants of Lactobacillus acidophilus. Appl Environ Microbiol 41, 1461-1467.

Lillehaug, D. (1997) An improved plaque assay for poor plaque-producing temperate lactococcal bacteriophages. J Appl Microbiol 83, 85-90.

Moineau, S. (1999) Applications of phage resistance in lactic acid bacteria. In Proceedings of the Sixth Symposium on Lactic Acid Bacteria: Genetics, Metabolism and Applications ed. Konings, W.N., Kuipers, O.P. and Huis in 't Veld, J.H.J. pp. 377-382. Veldhoven, the Netherlands: Kluwer Academic Publishers.

Moineau, S. and Lévesque, C. (2005) Control of bacteriophages in industrial fermentations. In Bacteriophages: Biology and Applications ed. Kutter, E. and Sulakvelidze, A. pp. 285-296. Boca Raton, FL: CRC Press.

Monteville, M., Ardestani, B. and Geller, B. (1994) Lactococcal bacteriophages require a host cell wall carbohydrate and a plasma membrane protein for adsorption and ejection of DNA. Appl Environ Microbiol 60, 3204-3211.

Müller-Merbach, M., Kohler, K. and Hinrichs, J. (2007) Environmental factors for phage induced fermentation problems: replication and adsorption of the Lactococcus lactis phage $\mathrm{P} 008$ as influenced by temperature and $\mathrm{pH}$. Food Microbiol 24, 695-702.

Neve, H. (1996) Bacteriophage. In Dairy Starter Cultures ed. Cogan, T.M. and Accolas, J.P. pp. 157-190. New York, USA: VCH Publishers.

Neviani, E., Carminati, D. and Giraffa, G. (1992) Selection of some bacteriophage- and lysozyme-resistant variants of Lactobacillus helveticus CNRZ 892. J Dairy Sci 75, 905913.

Quiberoni, A. and Reinheimer, J. (1998) Physicochemical characterization of phage adsorption to Lactobacillus helveticus ATCC 15807 cells. J Appl Microbiol 85, 762-768.

Quiberoni, A., Guglielmotti, D., Binetti, A. and Reinheimer, J. (2004) Characterization of three Lactobacillus delbrueckii subsp. bulgaricus phages and the physicochemical analysis of phage adsorption. J Appl Microbiol 96, 340-351.

Reinheimer, J.A., Morelli, R., Callegari, M.L. and Bottazzi, V. (1993) Phage resistance in Lactobacillus helveticus CNRZ 328. Microbiol Aliments Nutr 11, 235-240.

Reinheimer, J., Suárez, V.B., Bailo, N. and Zalazar, C.A. (1995) Microbiological and technological characteristics of natural whey cultures of Argentinian hard-cheese production. J Food Prot 58, 796-799.

Reinheimer, J., Quiberoni, A., Tailliez, P., Binetti, A. and Suárez, V. (1996) The lactic acid microflora of natural 
whey starters used in Argentina for hard cheese production. Int Dairy J 6, 869-879.

Séchaud, L., Cluzel, P.-J., Rousseau, M., Baumgartner, A. and Accolas, J.-P. (1988) Bacteriophages of lactobacilli. Biochimie 70, 401-410.

Sijtsma, L., Sterkenburg, A. and Wouters, J. (1988) Properties of the cell walls of Lactococcus lactis subsp. cremoris SK110 and SK112 and their relation to bacteriophage resistance. Appl Environ Microbiol 54, 2808-2811.

Suárez, V., Quiberoni, A., Binetti, A.G. and Reinheimer, J.A. (2002) Thermophilic lactic acid bacteria phages isolated from Argentinean dairy industries. J Food Prot 65, 15971604.

Suárez, V., Capra, M., Rivera, M. and Reinheimer, J. (2007) Inactivation of calcium-dependent lactic acid bacteria phages by phosphates. J Food Prot 70, 1518-1522.

Suárez, V., Maciel, N., Guglielmotti, D., Zago, M., Giraffa, G. and Reinheimer, J. (2008a) Phage-resistance linked to cell heterogeneity in the commercial strain Lactobacillus delbrueckii subsp. lactis Ab1. Int J Food Microbiol 128, 401-405.

Suárez, V., Moineau, S., Reinheimer, J. and Quiberoni, A. (2008b) Argentinean Lactococcus lactis bacteriophages: genetic characterization and adsorption studies. J Appl Microbiol 104, 371-379.

Suárez, V., Zago, M., Quiberoni, A., Carminati, D., Giraffa, G. and Reinheimer, J. (2008c) Lysogeny in Lactobacillus delbrueckii strains and characterization of two new temperate prolate-headed bacteriophages. J Appl Microbiol 105, 1402-1411.
Svensson, V. and Christiansson, A. (1991) Methods for phage monitoring. FIL-IDF Bull 263, 29-39.

Valsayevi, R., Sandine, W.E. and Geller, B.L. (1990) The bacteriophage kh receptor of Lactococcus lactis subsp. cremoris $\mathrm{KH}$ is the rhamnose of the extracellular wall polysaccharide. Appl Environ Microbiol 56, 1882-1889.

Veaux, M., Neviani, E., Giraffa, G. and Hermier, J. (1991) Evidence for variability in the phenotypic expression of lysozyme resistance in Lactobacillus helveticus. Lait 71, 7585.

Vescovo, M., Botazzi, V. and Prestini, P. (1990) Different phage sensitivity in morphological variants of Lactobacillus delbrueckii spp. bulgaricus LB6. Ann Microbiol 40, 197-204.

Viscardi, M., Capparelli, R., Di Matteo, R., Carminati, D., Giraffa, G. and Iannelli, D. (2003a) Selection of bacteriophage-resistant mutants of Streptococcus thermophilus. J Microbiol Meth 55, 109-119.

Viscardi, M., Capparelli, R. and Iannelli, D. (2003b) Rapid selection of phage-resistant mutants in Streptococcus thermophilus by immunoselection and cell sorting. Int J Food Microbiol 89, 223-231.

Zago, M., Comaschi, L., Neviani, E. and Carminati, D. (2005) Investigation on the presence of bacteriophages in natural whey starters used for the production of Italian longripened cheeses. Milchwissenschaft 60, 171-174.

Zago, M., Rossetti, L., Bonvini, B., Remagni, M., Perrone, A., Fornasari, M.E., Carminati, D. and Giraffa, G. (2008) Il sieroinnesto di Grana Padano: una comunità di batteri e batteriofagi. Sci Tech Latt Cas 59, 277-286. 